\title{
Csongrád megye talajainak szélcsatorna kísérletekre alapozott szélerózió veszélyeztetettség becslése
}

\author{
*BARTus Máté, BARTA Károly, SzATMÁRi József, FARSANG Andrea
}

Szegedi Tudományegyetem, Természeti Földrajzi és Geoinformatikai Tanszék, Szeged (Beérkezett: 2019.09.01.; Elfogadva: 2019.11.14.)

\section{Bevezetés}

A hazai klímamodellezés fejlődésének köszönhetően az utóbbi években egyre pontosabb és részletesebb éghajlat-változási prognózisok jelentek meg a hazai szakirodalomban is. A hosszabb távú klimatológiai elörejelzések (MIKA et al. 1995; WEIDINGER et al. 2000; BARTHOLY, MiKA 2005; BARTHOLY et al. 2006; MeZÖSI et al. 2014) az elkövetkezö évtizedekre a nyári félévek hömérsékletének emelkedését, illetve csapadékának csökkenését prognosztizálják. Az adatok arra utalnak, hogy a Duna-Tisza közén további, fokozatosan gyorsuló szárazodási folyamat játszódhat le (KERTÉSZ et al. 2000; KovÁCS 2006), így a változó klimatikus feltételek 30-50\%-os növekedést eredményezhetnek a szélerózió dinamikájában (MEZÖsI 1996).

Az aszály alapvetően természeti jelenség, de közvetett módon igen jelentősen befolyásolja az emberi tevékenység is. Az elörejelzésének bizonytalansága meglehetősen nagy. Károkozó hatása nagymértékben függ az adott terület aszályérzékenységétöl. CSORBA és munkatársai (2012) a modell szimulációikat a Pálfai-féle aszályindex (PAI) módosított változatának (Palfai Drought Index, PaDI) alkalmazásával végezték. Ezek alapján egyértelmünek látszik, hogy a jövőben a fokozódó szárazodás hatására a talajok víztartalma csökkenni, ezzel együtt a defláció mértéke és az általa érintett terület nagysága növekedni fog. Az eredmények azt mutatják, hogy a szárazodás következtében a 2021-2050 közötti időszakra a szélerózió szempontjából közepesen veszélyeztetetté válik az ország területének jelentős része. A leginkább érintett térségek a Duna-Tisza köze, Duna-menti sík, Gödöllői-dombság, valamint Belső-Somogy. A szárazodás fokozódásával a 2071-2100 közötti idöszakra a szélerózió-veszélyeztetettség tovább fog nőni, amelynek során a Mezőföld, valamint a Marcal-medence és a Komárom-Esztergomi-síkság területe is erősen veszélyeztetetté válik (CsORBA et al. 2012; FARSANG 2016).

BORELLI (2014) Európa nagy részét lefedő kutatása alapján azt találta, hogy a kontinens felszínének 4,9\%-a erösen és 13,8\%-a pedig közepesen erózió veszélyeztetett kategóriáiba esik - Borelli a LUCAS (Land Use/Land Cover Area Frame Statistical Survey) adatbázisban szereplő talajminták alapján számolt EF és SCF-értékek segítségével becsült. A szélerózióval sújtott területek aránya Magyarországon szintén jelentős. Hazánk területének kb. 26\%-án közepes és súlyos a potenciális defláció veszélyeztetettség (2,6 millió hektár), LÓKI (2003) ezen besorolást a talajok fizikai féleségére alapozta. Főleg a nagy kiterjedésü

*Levelezö szerzö: BARTUS MÁTÉ, Szegedi Tudományegyetem, Természeti Földrajzi és Geoinformatikai Tanszék, 6726 Szeged Egyetem u. 2-6

E-mail: bartus.mate@gmail.com 
homokterületek vannak veszélyben, mint például Belső-Somogy, a Kiskunság vagy a Nyírség, de az erózió elleni védelem rendkívül fontos az értékesebb csernozjom talajjal rendelkező DK-i országrészben is (BARCZI, CENTERI 2005). A Duna-Tisza közén a deflációval veszélyeztetett területek aránya eléri a 23\%-ot (SZATMÁRI 2006). PÁSZTOR és munkatársai (2016) - akik a talajok fizikai félesége mellett az adott terület szél sebességén túl a felszínborítást is használták az osztályozáskor kutatásait alapul véve hazánk területének 4,7\%-a az erösen és 5,7\%-a a közepesen szélerózió veszélyeztetett kategóriába tartozik.

A szélerózió tudományos megközelítése több irányból és célkitűzéssel történhet. Terepi in situ kísérletekkel és mérésekkel valós szélesemények alkalmával követhetőek nyomon legérzékenyebben a változások (eróziós tük kihelyezése, szediment csapdák elhelyezése stb.) (SZATMÁRI 2006). A lejátszódó folyamatok aprólékos modellezése szélcsatornában lehetséges, ahol tetszés szerint változtatható a szélsebesség, a talajparaméterek, a felszín érdessége és nedvességtartalma és még sok egyéb tényező. A szélcsatornák két típusa használatos a kutatásban: laboratóriumi szélcsatornák, ahová a vizsgált talajanyag beszállításra kerül, illetve terepi szélcsatornák, melyekkel lehetőség nyílik bolygatatlan talajfelszíneken is méréseket végezni (LÓKI 1994, 2003; BACH 2008). A laborkörülmények közötti vizsgálatok némi hibalehetőséget rejtenek magukban a talaj szerkezetének bolygatása, szállítás közbeni leromlása, valamint az alkalmazott minta előkészítési eljárások (szárítás, törés, szitálás) miatt. A terepi szélcsatornával végzett kísérletek már pontosabban közelítik a valós széleróziós értékeket, hátránya viszont jelentős költségigénye, valamint az, hogy a terepi körülmények között végzett vizsgálatok nehezebben standardizálhatók. Az első szélcsatorna kísérletek az 1940-es években indultak (BAGNOLD 1941; CHEPIL 1945a,b; CHEPIL, ZINGG 1953; BORSY 1972) és elsősorban a szélerózió hatótényezőinek mind pontosabb megértésére, leírására irányultak. Napjainkban is számos kutatócsoport vizsgálja szélcsatornában a szélerózió törvényszerüségeit, elsősorban a hatótényezők közti matematikai összefüggések feltárására, valamint egyre inkább a széleróziós jelenségek off-site hatásainak becslésére (DREGNE 1988; FARSANG 2016; LÓKI, SZABÓ 1996; LÓKI, SZABÓ 1997; GOOSSENS et al. 2000; DONG et al. 2004; LÓKI 2000, 2001; TATÁRVÁRI, NÉGYESI 2013; KOUCHAMI-SARDOO et al. 2019).

A szélerózió következményei szerteágazók. A termőföldeken (on-site) a felső - egyben a tápanyagokban leggazdagabb - réteg megmozgatásával tápanyag csökkenést vagy helyenként felesleges felhalmozódást okozhat (FARSANG et al. 2011). A talajrészecskék mozgása kárt okozhat a növényzetben. A széleróziós területeken kívüli (off-site) hatásként a területről távozó részecskék akadályozhatják a közlekedést, a gépek amortizációját okozhatják, belélegezve pedig az élőlények egészségromlásáig vezethetnek. KORCZ és munkatársai (2009) megállapították, hogy az Európai Unió PM10 kibocsátásának 52\%-a származik a mezőgazdaságból. A szélerózió által okozott hatások térbeli kiterjedése is változatos. Lehetnek lokálisak, de lehetnek regionálisak is. Gondoljunk például arra, hogy az Ebinurtóból a kiszáradása után az elszállított sós szedimentet 200 km-re is kimutatták (ABUDUWAILI et al. 2008). De lehet egy egész kontinensre kiterjedő, mint az 
1930-as években az USA-ban bekövetkezett Dust Bowl, mikor 2,5 millió embernek kellett elvándorolnia (CHEPIL 1957), vagy Ausztráliában a 2009-es „Red Dawn”, ami az addig mért legnagyobb talajveszteségét - a becsült tömeg 2,54 Mt volt okozta (LEYs et al. 2011). A szélerózió kialakulásának esélye és negatív hatásai megfelelő gazdálkodási gyakorlattal megelőzhetők, mérsékelhetők. Legyen szó a talajfelszín tulajdonságának módosításáról (CHEPIL, WOODRUFF 1963; BODOLAYI et al. 1976; MicHELS et al. 1995; Touré et al. 2019), a termőföld méretének (CHEPIL 1957) vagy környezetének módosításáról (VIGIAK et al. 2003; BARTUS et al. 2013, 2017).

A szélerózió nemcsak a laza szerkezetü homoktalajokat érinti, hanem a kötöttebb talajokon is jelentős károkat okozhat (BODOLAY 1966; FARSANG et al. 2011, 2013; BOLLES et al. 2019). Szélerózió akkor alakul ki, amikor a szél energiája elég nagy ahhoz, hogy a szemcséket mozgásba hozza a talajfelszínen, a szemcséket mozgásba hozó szélsebességet nevezzük kritikus indítósebességnek. Minél nagyobb a szél sebessége, annál nagyobb részecskéket képes mozgásba hozni. WANG és munkatársai (2019) kimutatták, hogy a szélsebesség növekedésével a mozgásba hozott hordalék szemcsemérete exponenciálisan nő. A hazai kritikus indítósebesség kutatásának indulása Borsy Zoltán nevéhez köthető (BORSY, 1972), aki szélcsatornát épített a Debreceni Egyetemen, ezáltal elősegítve a pontosabb méréseket. Az ő munkásságát folytatta Lóki József (LóKI 2001, 2003, 2011) és Négyesi Gábor (NÉGYESI et al. 2016) is. Jelen kutatásunk során az eddigi kutatási eredményekre alapozva (FARSANG et al. 2011, 2013) különböző fizikai féleségú talajokat vizsgálva határoztuk meg a kritikus indítósebesség értékeket szélcsatornában, valamint kapcsolatokat kerestünk az egyes talajtani alaptulajdonságok és a kritikus indítósebesség értékek között. A mért értékek alapján elkészítettük Csongrád megye szélerózió veszélyeztetettségi térképét.

\section{Anyag és módszer}

Kutatásunk mintaterületeként Szeged környékét (1. ábra) határoztuk meg. A Dél-Alföld változatos talajtípusai segítségével átfogó képet kaphatunk a szélerózió érzékenység vizsgálathoz. A mintaterület az Alsó-Tisza-vidék középtájon, s ezen belül a Dél-Tisza-völgy kistájon található, amely a Tisza irányába lejtő tökéletes síkság. Domborzatára jellemző a 80-101 m B. f. magasság (DöVÉNYI 2010). Éghajlata meleg, száraz. A napsütéses órák száma évi 2000-2050 közötti, az évi középhőmérséklet $10,6{ }^{\circ} \mathrm{C}$, a tenyészidőszak középhömérséklete $17,4-17,6{ }^{\circ} \mathrm{C}$. Az évi csapadékösszeg $600 \mathrm{~mm}$ körüli, de előfordul $1000 \mathrm{~mm} \mathrm{év}^{-1}$ is, ugyanakkor az extrém száraz években $300 \mathrm{~mm}$ alá is csökkenhet a csapadék, mely jelentösen megnöveli a szélerózió veszélyét (FARSANG 2016, 2017).

A közel negyven mintavételi hely kiválasztásának legfőbb szempontja a területre jellemző változatos talajtakaró reprezentatív megmintázása volt. Az egyes mintavételi helyeken egy kb. 2 m-es kört kijelölve vettünk a feltalajból (felső $5 \mathrm{~cm}$-es rétegböl) talajmintát, helyszínenként kb. 5-6 kg-ot. A mintákat gondosan lezárva szállítottuk a szélcsatornához további vizsgálatokra. 


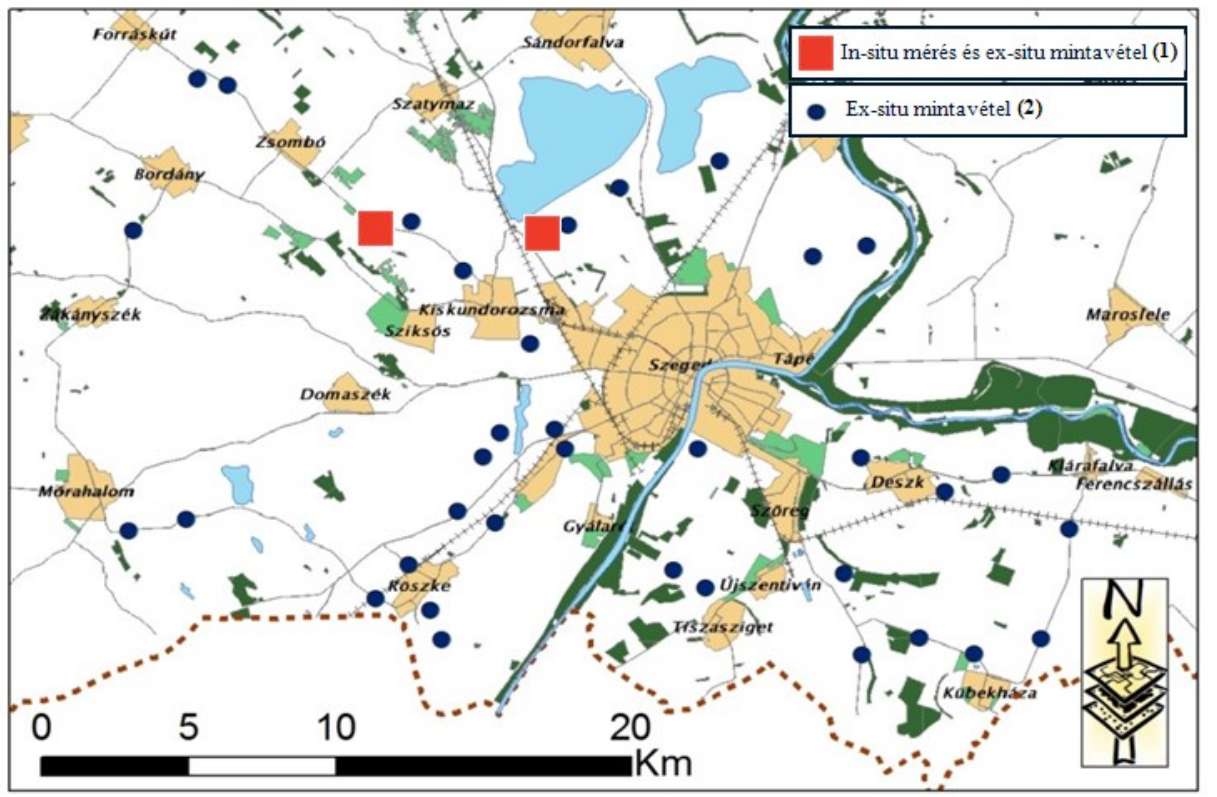

1. ábra

Szeged környéki mintavételi pontok (körlap jelöli az ex-situ mintavételi pontokat, négyzet az in-situ mérési és ex-situ mintavételi pontokat)

A kísérlet sorozatokhoz egy $12 \mathrm{~m}$ hosszú, $0,7 \mathrm{~m}$ széles és $0,75 \mathrm{~m}$ magas szélcsatornát használtunk. A szélcsatorna több részböl áll. Egy nagy teljesítményü, $1,2 \mathrm{~m}$ átméröjü ventilátor biztosította a légáramlatot, melyet egy 7,5 kW-os villanymotor hajtott meg. A nagyfeszültségü áramot aggregátor szolgáltatta. A ventilátort egy flexibilis cső követi, amely egy ún. laminátor részhez csatlakozik. A laminátor egy fémvázból és hálószerüen egymásra telepített csövekből áll, és célja az áramló levegőben a turbulenciák megszüntetése. A laminátort egy szükítő elem követi, amely immár egyenes vonalú légáramlatot vezet egy héttagú (egyenként 80 x 70 x $75 \mathrm{~cm}$, összesen 5,6 m hosszú), alul nyitott szélcsatornába (FARSANG et al. 2011).

A terepi körülmények között - in-situ - végzett mérések során a szélcsatornában megfújatott talajfelszín összesen $3,92 \mathrm{~m}^{2}$ nagyságú. A $7 \mathrm{db}$ elemből álló szélcsatornatest egyik oldala átlátszó műanyagból készült, így megfigyelhetővé válik a talaj mozgása, és ezzel detektálható minden egyes kísérletnél a kritikus indítósebesség. Az ex-situ szélcsatorna kísérletek során egy 40x50 cm-es $\left(0,2 \mathrm{~m}^{2}\right)$ és $5 \mathrm{~cm}$ mély mintatartót helyeztünk a szélcsatornába, s ebbe kerültek a mintaterületen gyüjtött talajminták (2. ábra). A talajok kritikus indítósebességének meghatározásához a szélsebességet a korábbi kutatásunkkal megegyezően a talajfelszín felett $10 \mathrm{~cm}$ magasságban mértük (FARSANG et al. 2011). A szélsebesség meghatározásához Lambrecht Jürgens 642 anemométert használtunk. 
A kísérlet megkezdése előtt azzal számoltunk, hogy az ex-situ mérések során a mért kritikus szélsebességi értékeket nem használhatjuk kalibrálás nélkül, mert csupán a bolygatás vagy a jóval kisebb felületen mért kritikus indítósebesség már módosító tényezők lehetnek. Ezekre a módosító tényezőkre, mint mérési módszerek közötti különbség tekintettünk. Annak okán, hogy minél jobban megközelítsük az ex-situ mérési eredményeinkkel az in-situ környezetben mért eredményeink használhatóságát, mind az in-situ és mind az ex-situ környezetben több mérést hajtottunk végre ugyanazon a mintaterületen, illetve a mintaterületről gyüjtött mintán (egy homok és egy vályog terület). Az eredményeket összehasonlítva határoztuk meg azt a kalibrálási értéket, mellyel finomítani tudtuk az ex-situ mérési értékeinket.

Az időjárási adatokat a Szegedi Meteorológiai állomás (WMO index: 12982) 2000-2019 közötti SYNOP-táviratai feldolgozásával nyertük. A vizsgálatunk során a szélerózió szempontjából kritikus időszakokat válogattuk le az időjárási adatokból - ugyanúgy, mint a WEQ modell esetében (CARLSON et al. 1999; TATARKO et al. 2013). Ennek okán csak márciusi és az áprilisi adatokat dolgoztuk fel, mivel a vizsgálni kívánt szántóterületeken ebben az időszakban az egyik legkevésbé védett a talajfelszín. Ez időben a felszínt már nem védi a hó, de még nem fejlődött ki a növényzet, ami megóvná a talajt a széleróziótól (CHEPIL, WOODRUFF 1963).

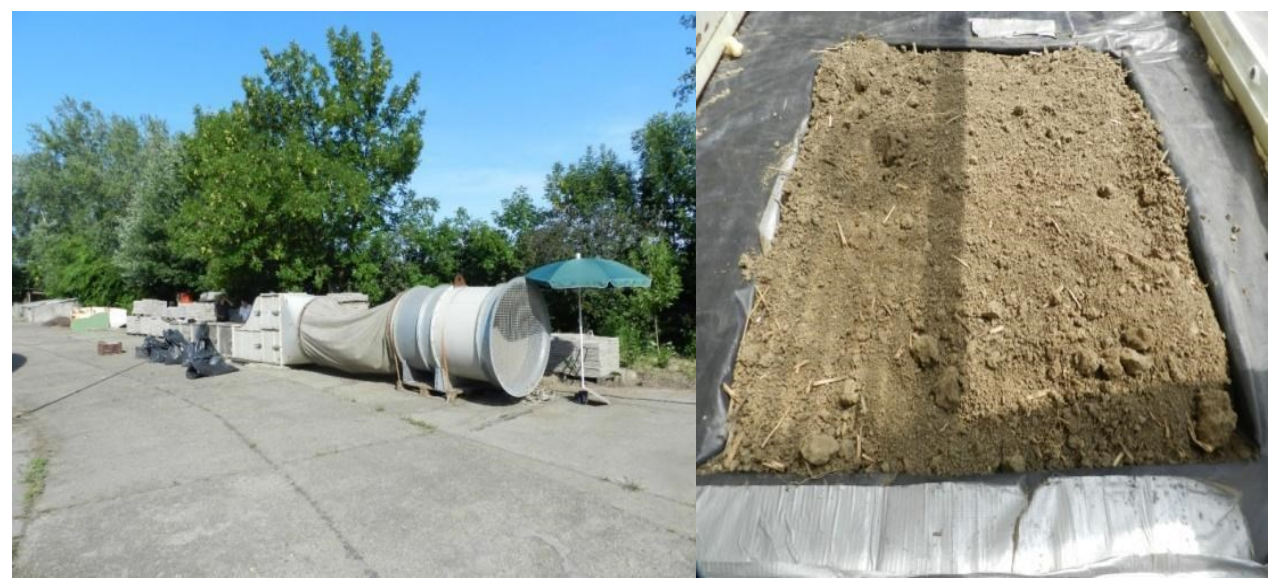

2. ábra

A szélcsatorna mérések körülményei: a felállított szélcsatorna (balra) és a fújatási felszínbe mélyített mintatartó (jobbra)

Az időjárási és széleróziós adatok együttes elemzésével megbecsültük a Szeged környéki talajok éves széleróziós veszélyeztetettségét. Először a főbb fizikai talajféleségeknél mért kritikus indítósebességeket átlagoltuk, melyhez a szélcsatorna vizsgálatok során $10 \mathrm{~cm}$ magasságában mértük meg a kritikus indítósebességet majd ezt az értéket kiszámoltuk 10 méter magasságra is. A különböző magasságokba történő átszámítást a nyírósebesség - azaz $0 \mathrm{~cm}$ 
magasságra számolt szélsebesség - és az aerodinamikai érdesség segítségével határoztuk meg (1. képlet).

$$
\mathrm{U}_{\mathrm{z}}=\frac{\mathrm{U}_{0}}{\mathrm{C}} * \ln \frac{\mathrm{Z}-\mathrm{D}}{\mathrm{Z}_{0}}
$$

\section{1. képlet}

Szélsebesség kiszámítása különböző magasságokra, ahol: $U_{z}$ : szélsebesség nagysága $Z$ magasságban; $\mathrm{U}_{0}$ : a nyírási sebesség; $\mathrm{C}$ : Von Kármán- féle konstans, értéke 0,$4 ; \mathrm{Z}$ : a szélsebesség mérésének magassága; $\mathrm{D}$ : az elmozdítás magassága; $\mathrm{Z}_{0}$ : az aerodinamikai érdesség. (ZHANG et al. 2004)

$\mathrm{Az}$ 1. képletben látható aerodinamikai érdesség meghatározásához a széleróziós mérések során megmértük az összes talajfelszínhez tartozó szélsebesség profilt, melyhez a talajfelszín felett 4 magasságban $(5 ; 10 ; 15 ; 20$ centiméter) mértük az ugyan ahhoz a szélsebességhez tartozó szélsebesség értékeket. Minél nagyobb egy talajfelszín aerodinamikai érdessége, annál jobban fékezi, lassítja a fölötte haladó szél sebességét. Az így kapott szélprofil logaritmikus görbéjéböl meghatározott regressziós egyenlettel számoltuk ki az aerodinamikai érdességet (ZHANG et al. 2004). Ezt követően az agrotopográfiai adatbázis alapján minden egyes fizikai féleséghez leválogattuk az adott fizikai féleséghez tartozó kritikus indítósebességnél nagyobb sebességgel jellemezhető széleróziós eseményeket. Végül a SYNOP-táviratokból kinyerhető adatokat elemezve határoztuk meg a széleróziós eseményeket. Egy széleróziós esemény alatt egy olyan időblokkot értünk, ami akkor kezdődik, amikor a SYNOP-táviratokból kinyerhető órás átlagszélsebesség (10 méter magasságban mért 10 perces átlag sebességérték) átlépi a talajfelszín kritikus indítósebességét és egészen addig tart, amíg a szélsebesség értékek afölött vannak. A széleróziós eseményeket az események számával és hosszával jellemeztük.

A talajok aggregátumos szerkezetének, a nedvességtartalmának és a talajtani tulajdonságainak meghatározásai a Szegedi Tudományegyetem Természeti Földrajzi és Geoinformatikai Tanszék akkreditált Talaj- és Vízvizsgálati Laboratóriumában történtek. A talajok nedvességtartalmának meghatározása gravimetriásan történt az MSZ 08-0205:1978 szabvány szerint, melyhez kb. 300g talajmintát használtunk fel. A minták aggregátumos szerkezetének meghatározására a nedvességtartalom meghatározása után megmaradt talajmintákat használtuk fel. A mérés során leszitáltuk őket (a szita sor lyukátmérői mm-ben: >20,0; 20,0-10,0; $10,0-5,0 ; 5,0-3,15 ; 3,15-2,0 ; 2,0-1,0 ; 1,0-0,63 ; 0,63-0,5 ; 0,5-0,315 ; 0,315-0,25$; $0,25-0,1 ; 0,1-0,063 ;<0,063$ ) és a szitákon fennmaradt talaj tömegét mértük le. A $10,0 \mathrm{~mm}$-nél nagyobb szerkezeti elemeket rög, a $10,0 \mathrm{~mm}$ és a $0,25 \mathrm{~mm}$ közötti elemeket morzsa és a $0,25 \mathrm{~mm}$-nél kisebb elemeket pedig por frakcióba soroltuk (STEFANOVITS et al. 2010). 


\title{
Eredmények és értékelés
}

\author{
A talajtani alapvizsgálatok és a kritikus inditósebesség kapcsolata
}

\section{Nedvességtartalom}

A kritikus indítósebesség egyik legmeghatározóbb tényezője a talajok nedvességtartalma. A minták nedvességtartalma 0,0-6,3\% között változott. WEINAN és munkatársai (1996) kutatása megmutatta, hogy ha a talajok nedvesség értéke eléri a 4\%-ot, akkor a nedvességtartalom lesz a döntő tényező a kritikus indítósebességben. Hogy a talajok más tulajdonságainak hatását érdemben vizsgálni tudjuk, kizártuk azon mintákat (összesen kettőt) a további vizsgálatokból, ahol a nedvességtartalom meghaladja a 4\%-ot.

\section{Kémhatás, $\mathrm{CaCO}_{3}$ tartalom}

A talajok kémhatása a gyengén savanyú és a gyengén lúgos értékek (6,4-8,0 pH) között változott (KEVEINÉ, FARSANG 2008). A kémhatás indítósebességre gyakorolt hatását tekintve megállapítható, hogy nincs markáns kapcsolat a két érték között. A kémhatás és az indítósebesség Pearson-féle korrelációs kapcsolata $\mathrm{r}=-0,374 ; 0,005$ szignifikancia szinten. A talajok mésztartalma fontos tényező a talajok aggregátum szerkezetének kialakulásában, a talajrészecskék közötti mész elösegíti a részecskék összetapadását, így az aggregátum szerkezetet kialakulását, amely ellenállóbbá teszi a talajokat a szélerózió hatásával szemben. A talajminták mésztartalma a gyengén meszes és a közepesen meszes kategóriába esik (0,0-19,0\%) (KEVEINÉ, FARSANG 2008). Az indítósebességre gyakorolt hatást tekintve elmondható, hogy a mésztartalom és a kritikus indítósebesség között nem volt szignifikáns kapcsolat, a korreláció mértéke elhanyagolható (Pearson-féle korreláció $\mathrm{r}=-0,030)$.

\section{Fizikaiféleség}

A talajok fizikai félesége meghatározó tulajdonság az agronómiai szerkezet és az indító sebesség szempontjából. A talajminták fizikai féleségének meghatározására az Arany-féle kötöttségi értéket használtuk. A talajmintákat fizikai féleség szerint négy csoportba soroltuk: homok $(n=7)$, homokos vályog $(n=11)$, vályog $(n=5)$, agyagos vályog $(n=8)$ és agyag $(n=1)$. A talajok fizikai féleségének az indító sebességre gyakorolt hatását a 3. ábra mutatja be. Az ábrán látható, hogy az Arany-féle kötöttségi szám növekedésével növekszik a talajok indítósebessége. Az Arany-féle kötöttség és az indítósebesség között exponenciális összefüggés van a determinisztikus együttható $\left(\mathrm{R}^{2}\right) 0,4313$. 


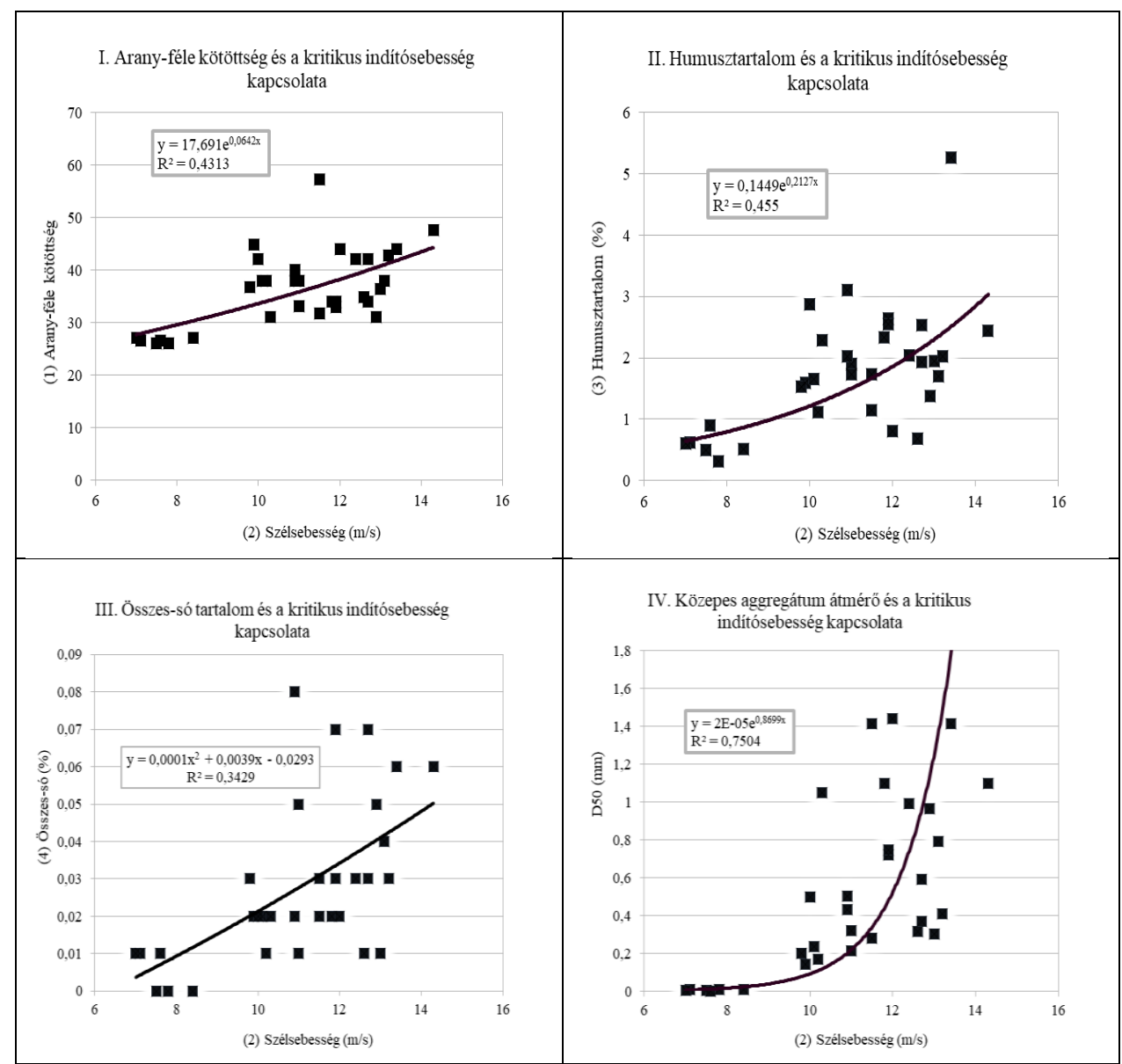

3. ábra

A talaj fizikai féleségének, humusz és összes-só tartalmának, valamint közepes aggregátum átmérőjének hatása a kritikus indítósebességre

\section{Humusz tartalom}

A talajok agronómiai szerkezetének kialakulásának másik fontos eleme a talajok humusztartalma. A vizsgált talajminták humusztartalma - néhány kivételtől eltekintve $-3 \%$ alatt marad, s általánosságban elmondható, hogy a homoktalajok humusztartalma a legalacsonyabb, míg a homokos vályog - vályog fizikai féleségü csernozjomok humusztartalma a legmagasabb. A humusztartalom és az indítósebesség közötti összefüggést az 3 . ábra mutatja be, mely alapján a talajok humusztartalmával exponenciálisan növekszik az indítósebesség értéke $\left(\mathrm{R}^{2}=0,455\right)$. 
Összes-só tartalom

A vizsgált területek feltalajaiban az összes-só tartalma 0,0 és $0,08 \%$ között változik (3. ábra). Az összes-só tartalom és a kritikus indítósebesség között másodfokú függvénykapcsolat van ( $\mathrm{R}^{2}$ értéke 0,3429$)$.

\section{Agronómiai szerkezet}

A talajminták agronómiai szerkezetének vizsgálata során megállapítottuk a három agronómiai frakció arányának (rög $(>10 \mathrm{~mm})$, morzsa $(0,25-10 \mathrm{~mm})$ és por $(<0,25 \mathrm{~mm}))$ és a kritikus indítósebességnek egymásra gyakorolt hatását. A rög és morzsa frakció esetében pozitív, míg a por frakció esetében negatív korrelációt fedeztünk fel a kritikus indítósebesség viszonyában. A három frakció közül a por frakció aránya (Pearson korreláció, $\mathrm{r}=0,871 ; 0,01$ szignifikancia szinten) mozgott együtt leginkább a kritikus indítósebességgel. Ugyanez az érték a morzsa és rög frakciók esetében: $\mathrm{r}=0,779$ és $\mathrm{r}=0,656$ szintén 0,01 szignifikancia szinten. Az agronómiai szerkezet másik fontos jellemzője a közepes aggregátumátmérő (D50). A közepes aggregátum átmérő és a kritikus indítósebesség között exponenciális kapcsolatot találtunk (3. ábra, $\left.\mathrm{R}^{2}=0,7504\right)$. A nagyobb méretű aggregátumok jelenlétében lényegesen lassabban indul meg a szélerózió, a nagyobb szemcsék kritikus szélsebesség növelő hatásáról számol be SHAHABINEJAD és munkatársainak a munkája (2019) is.

\section{Talajfelszinek kritikus inditósebessége és aerodinamikai érdessége}

A talajminták kritikus indítósebességeit és az aerodinamikai érdességét az 1. táblázatban mutatjuk be. A táblázatban a mintákat a fizikai féleségük szerint csoportosítottuk, amely a későbbi térképi kiterjesztés végett volt szükséges. A táblázatban szereplő agyag fizikai féleség csoportot kizártuk a vizsgálatainkból, mert kritikus indító sebességet csupán egy minta esetében sikerült mérni. A mintákra meghatározott aerodinamikai érdesség értéke (1. Táblázat, $Z_{0}$ érték) nagyságrendileg megegyezik a ZHANG és munkatársai (2004) által mért eredményekkel, illetve a korábbi terepi kutatásaink eredményeivel (FARSANG et al. 2013a, 2013b). Az 1. táblázatból kiolvasható, hogy a kritikus indítósebesség növekedésével, illetve a talajok kötöttségi értékeivel együtt nő az aerodinamikai érdesség, az aerodinamikai érdesség és a kritikus indítósebesség ezen összefüggése az irodalmi adatokkal megegyezik (FRYREAR, SKIDMORE 1985).

Az ex-situ szélcsatornás vizsgálatok korlátai miatt az eddig említett kritikus indítósebesség értékek csupán egy relatíve kis talajfelszín mérésével lettek meghatározva. A pontosabb kritikus indítósebesség érték meghatározására felhasználtuk a 2013 során elvégzett in-situ kísérleti sorozatunk eredményeit (FARSANG et al. 2013a, 2013b; FARSANG 2017). Az in-situ és ex-situ méréseket összehasonlítva megállapíthatjuk, hogy az in-situ körülmények között mért kritikus indítósebesség értékek az ex-situ körülmények között mért értékek 72,5\%-a. Ezt az értéket $14 \mathrm{db}$ homok és vályog fizikai féleségen mért in-situ terepi mérésen, illetve 9 db ugyanazon fizikai féleségeken mért ex-situ vizsgálat átlagából határoztuk meg. 
A különbséget, mint az ex-situ - in-situ mérési módszer különbségének tekintettük, ezért az ex-situ mérések eredményeit mind az 5 fizikai féleségnél ezen százalékos értékkel korrigáltuk (1. táblázat). Mint korábban említettük, a különbséget a bolygatás és az eltérö fújatási felületek okozhatják.

A korrigált, 10 méter magasságra kiszámolt kritikus indítósebesség értékeket $\left(K_{o r r} U t_{10 m}\right)$ a 1. táblázatban mutatjuk be. A kritikus indítósebesség értékek a kötöttség növekedésével együtt nőnek, a két érték közötti hasonló összefüggésre hívta fel a figyelmet TATÁRVÁRI és NÉGYESI (2013).

\begin{tabular}{|c|c|c|c|c|c|}
\hline $\begin{array}{c}\text { Fizikai-féleség } \\
\text { (1) }\end{array}$ & $\begin{array}{l}\text { Homok } \\
\text { (2) }\end{array}$ & $\begin{array}{l}\text { Homokos- } \\
\text { vályog (3) }\end{array}$ & $\begin{array}{l}\text { Vályog } \\
\text { (4) }\end{array}$ & $\begin{array}{c}\text { Agyagos-vályog } \\
\text { (5) }\end{array}$ & $\begin{array}{c}\text { Agyag } \\
\text { (6) }\end{array}$ \\
\hline Mintaszám (a) & 6,0 & 11,0 & 6,0 & 8,0 & 1,0 \\
\hline $\mathrm{Ut}_{10 \mathrm{~cm}} *\left(\mathrm{~m} \mathrm{~s}^{-1}\right)(\mathrm{b})$ & 7,6 & 11,8 & 11,0 & 12,2 & 11,5 \\
\hline $\mathrm{Ut}_{10 \mathrm{~cm}} *$ Szórás (c) & 0,5 & 1,1 & 1,1 & 1,6 & n.é. \\
\hline $\begin{array}{l}\operatorname{KorrUt}_{10 \mathrm{~m}} * * \text { Átlag } \\
\left(\mathrm{m} \mathrm{s}^{-1)}(\mathrm{d})\right.\end{array}$ & 8,2 & 12,3 & 12,5 & 14,0 & 12,6 \\
\hline $\begin{array}{l}\text { KorrUt }{ }_{10 \mathrm{~m}} * * \text { Szórás } \\
\text { (e) }\end{array}$ & 0,7 & 1,8 & 2,2 & 2,6 & n.é. \\
\hline $\mathrm{Z}_{0} * * *(\mathrm{~m})(\mathrm{f})$ & 0,00002 & 0,00003 & 0,00004 & 0,00021 & 0,00001 \\
\hline $\mathrm{Z}_{0} * * *$ Szórás $(\mathrm{g})$ & 0,00004 & 0,00005 & 0,00006 & 0,00031 & n.é. \\
\hline \multicolumn{6}{|c|}{ * $\mathrm{Ut}_{10 \mathrm{~cm}}$ : kritikus indítósebesség $10 \mathrm{~cm}$ magasságban, ex-situ körülmények között } \\
\hline \multicolumn{6}{|c|}{$\begin{array}{l}\text { ** KorrUt }{ }_{10 m} \text { : in-situ mérések alapján korrigált kritikus indítósebesség } 10 \text { méter } \\
\text { magasságban }\end{array}$} \\
\hline \multicolumn{6}{|c|}{ *** $\mathrm{Z}_{0}$ : Aerodinamikai érdesség } \\
\hline \multicolumn{6}{|l|}{ n.é. nem értelmezhető } \\
\hline
\end{tabular}

\section{1. táblázat}

Dél-alföldi különböző fizikai talajféleségek kritikus indítósebessége, aerodinamikai érdessége

\section{Csongrád megye széleróziós veszélyeztetettsége}

A veszélyeztetettség megállapításához elsőként meghatároztuk, hogy mennyi ideig vannak kitéve a talajfelszínek a széleróziónak, és hogy hányszor fordul elő széleróziós esemény. Ezt követően lehatároltuk azon területeket, melyek érintettek a szélerózióval.

A további vizsgálatokban a homokos-vályog és vályog kategóriákat egy csoportba vontuk össze. Az összevonásnak az az oka, hogy a SYNOP adatokból kinyert adatok csupán egész számban jelzik a szélsebességet, így a kritikus indítósebesség értékeket figyelembe véve ugyanaz a szélsebesség képes mind a két talajfelszínen széleróziós eseményt kiváltani. Az összevonást az is indokolja, hogy a mintaterületen ez a két fizikai féleség jellemző a terület egyik markáns talajtípusát jelentő csernozjomokra, amelyek széleróziós viselkedése hasonló, ugyanakkor élesen elkülönül a homoktalajokétól. 
A széleróziós kitettség időbeli értékeit szintén az 2. táblázat tartalmazza, melyen látható, hogy a homoktalajokon egy nagyságrenddel nagyobb a széleróziós események és órák száma, mint a kötöttebb homokos vályog, vályog vagy agyagos vályog talajokon. Ezen értékek összefüggenek a talajok kritikus indítósebességi értékeinek növekedésével, mely megegyezik a korábbi terepi méréseinkkel és az irodalmi adatokkal (LÓKI 2001). A táblázatból látszik, hogy a vizsgált húsz év során az átlagos évi széleróziós eseményszám több, mint 16, és egy-egy ilyen esemény hossza átlagban 3 óra. Ugyanezek az értékek homokos vályog, vályog és agyagos vályog talajok esetében rendre 1,6 esemény és 1,4 óra, illetve 0,4 esemény és 1 óra. Ezek alapján elmondható, hogy az agyagos-vályog fizikai féleségü talajok esetében csak 3 évente lehet számítani egy-egy jelentősebb széleróziós eseményre.

\begin{tabular}{|l|c|c|c|}
\hline \multicolumn{1}{|c|}{$\begin{array}{c}\text { Fizikai-féleség } \\
\text { (1) }\end{array}$} & $\begin{array}{c}\text { Homok } \\
\text { (2) }\end{array}$ & $\begin{array}{c}\text { Homokos-vályog-Vályog } \\
\text { (3) }\end{array}$ & $\begin{array}{c}\text { Agyagos-vályog } \\
\text { (4) }\end{array}$ \\
\hline $\begin{array}{l}\text { Évenkénti átlagos } \\
\text { széleróziós össz- } \\
\text { időtartam (óra év } \text { (1) }^{-1} \text { (a) }\end{array}$ & 50,5 & 2,3 & 0,4 \\
\hline $\begin{array}{l}\text { Évenként átlagosan } \\
\text { előforduló széleróziós } \\
\text { esemény (esemény) (b) }\end{array}$ & 16,8 & 1,6 & 0,4 \\
\hline $\begin{array}{l}\text { Széleróziós események } \\
\text { átlagos hossza (óra) (c) }\end{array}$ & 3,0 & 1,4 & 1,0 \\
\hline
\end{tabular}

\section{2. táblázat}

Csongrád megyei talajfizikai féleségek szélerózió kitettség értékei (2000-2019-es SYNOP adatok alapján)

$\mathrm{Az}$ érintett területeken a rendelkezésre álló fizikai talajféleség (Agrotopográfiai térkép) - kritikus indítósebesség (1. táblázat) adatok párosításával elkészítettük Csongrád megye talajaira az egyes talajfelszínek kritikus indítósebesség érzékenységi térképét. A 4. ábrán látható Csongrád megyére vonatkozó széleróziós esemény értékek jól kiegészítik a korábbi kutatások során meghatározott szélerózió veszélyeztetettség térképeket (LÓKI 2001; MEZŐsI et al. 2015). Eredmény térképeink nem csak a különböző talajfelszínek széleróziós veszélyezettségének fokát adják meg, hanem azt is, hogy egy-egy területen mekkora a várható szélesemények száma egy évben.

A pontosabb területi érintettség meghatározása érdekében figyelembe vettük a felszínborítást, ehhez a Corine Land Cover 50 (CLC50) térképét használtuk. A területek meghatározása során csupán a Nagytáblás-szántóföldeket (CLC50-kód: 2111) és a Kistáblás-szántóföldeket (CLC50-kód: 2112 vettük figyelembe (3. táblázat). Elmondható, hogy Csongrád megye területének több mint a fele veszélyeztetett szélerózióval (57,5\%). Ezt az értéket árnyalhatjuk, ha a széleróziós kitettség (2. táblázat) és a széleróziós területek (3. táblázat) adatait vesszük figyelembe, így látható, hogy éves szinten 37,5\% kitett széleróziónak, valamint 20\%-án háromévente várható szélerózió. 


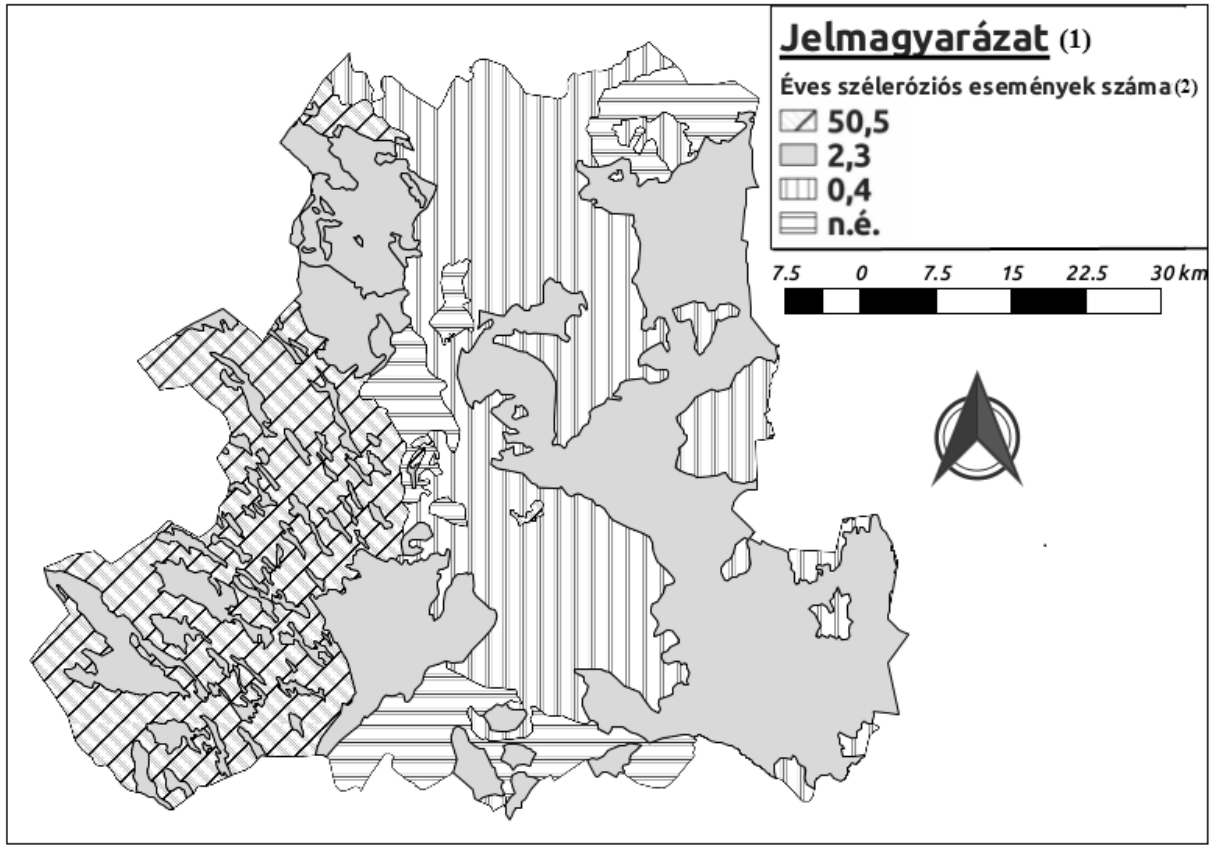

4. ábra

Csongrád-megye széleróziós eseményeinek éves száma (2000-2019)

\begin{tabular}{|l|c|c|c|}
\hline \multicolumn{1}{|c|}{$\begin{array}{c}\text { Fizikai féleség } \\
\text { (1) }\end{array}$} & $\begin{array}{c}\text { Homok } \\
\text { (2) }\end{array}$ & $\begin{array}{c}\text { Homokos vályog - Vályog } \\
\text { (3) }\end{array}$ & $\begin{array}{c}\text { Agyagos vályog } \\
\text { (4) }\end{array}$ \\
\hline $\begin{array}{l}\text { Csongrád-megyében érintett } \\
\text { terület }\left(\mathrm{km}^{2}\right) \text { (a) }\end{array}$ & 357,3 & 1241,6 & 853,9 \\
\hline $\begin{array}{l}\text { Csongrád-megyében érintett } \\
\text { terület (\%) (b) }\end{array}$ & 8,4 & 29,1 & 20,0 \\
\hline
\end{tabular}

3. táblázat

Csongrád megye szélerózióval veszélyeztetett területeinek mértéke a területhasználat figyelembevételével (Nagytáblás - és Kistáblás-szántóföldek)

\section{Összefoglalás}

A klímaváltozásnak köszönhetően a következő évtizedekben a talajok defláció veszélyezettségének mértéke emelkedni fog hazánkban (CsORBA et al. 2012). A kutatásunk során arra kerestünk választ, hogy a talajtani alaptulajdonságok miként befolyásolják a kritikus indítósebességet és jelenleg mennyire defláció veszélyeztetettek a Dél-Alföld talajai.

Mintaterületként a Szeged környéki talajokat választottuk. A vizsgálataink során megállapítottuk, hogy az összes vizsgált talajparaméter közül az agronómiai 
szerkezet, azon belül is a rögfrakció az, ami leginkább befolyásolja a kritikus indítósebességet. Ez felhívja a figyelmet az ember szerepére, aki megfelelő agrotechnikával képes lenne a széleróziós kockázat csökkentésére (BODOLAY 1966; SHAHABINEJAD et al. 2019). A szélcsatornás kritikus indítósebesség vizsgálatok eredményeit összevetettük az időjárási adatokkal, és ezek eredményeit kivetítettük Csongrád megye területére. Kutatásunk során meghatároztuk a széleróziós események jellemző éves előfordulását (homok: 16,8 esemény; homokos vályog és vályog 1,6 esemény; agyagos vályog: 0,4 esemény), ezen események átlagos hosszát (homok: 3,0 óra; homokos vályog és vályog 1,4 óra; agyagos vályog: 1,0 óra) és a deflációnak kitett területetek aránya Csongrád-megyében (homok: 8,4\%; homokos vályog és vályog 29,1\%; agyagos vályog: 20,0\%).

Kutatásunkkal képet kaptunk arról, hogy a defláció mekkora területet érint és mennyire jelentős talajvédelmi probléma Csongrád megyében. Korábbi kutatásaink bizonyítják, hogy egy párperces széleróziós esemény is súlyos veszteséget okozhat a talajok tápanyagtartalmából (FARSANG et al. 2011; FARSANG 2016), mely csupán csak egy aspektusa a szélerózió negatív hatásainak.

Kulcsszavak: szélerózió, defláció, szélerózió-veszélyeztetettség, szélcsatorna, kritikus indítósebesség

\section{Köszönetnyilvánítás}

A kutatást az OTKA 1K 116981, „Különböző talajtípusok defláció érzékenységének in situ szélcsatorna kísérletekre alapozott vizsgálata, on site és off site hatások". programja támogatta.

\section{Irodalom}

ABUDUWAILI J.,GABCHENKO M.V., JUNRONG X. 2008. Eolian transport of salts. A case study in the area of Lake Ebinur (Xinjiang, NorthwestChina) Journal of Arid Environments. 72.1843-1852.

BACH, M. 2008. Aolische Stofftransport ein Agrar landschaftem. PhD Dissertation. Christian-Albrechts Universitat zu Kiel, Kiel.

Bagnold, R.A. 1941. The Physics of Blown Sand and Desert Dunes. Methuen, London.

BARCZI A., CENTERI C. 2005. Az erózió és a defláció tendenciái Magyarországon. In: STEFANOVITS P, MichÉLI E. (szerk.) A termőföld jelentősége a XXI században. MTA TKK. Budapest. pp. 221-244.

BARTHOLY J., MiKA J. 2005. Időjárás és éghajlat - cseppben a tenger? - Magyar Tudomány. 7. 789-798.

Bartholy J., Pongrácz R., Torma C., Hunyady A. 2006. A Kárpát-medence térségére a XXI. Századra várható klímaváltozás becslése. III. Magyar Földrajzi Konferencia tudományos közleményei. CD kiadvány. 
BARTUs M., FARSANG A., SzATMÁRI J., BARTA K. 2013. Szélerózió becslése és modell alapú területhasználat optimalizáció a defláció veszélyeztetettség csökkentése érdekében, dél-alföldi mintaterületen. Talajvédelem. (Különszám) pp. 57-66.

BARTUS M., BARTA K., SZATMÁRI J., FARSANG A. 2017. Modeling winderosion hazard control efficiency with an emphasis on shelterbelt system and plotsize planning, Zeitschrift für Geomorphologie. 61. (2) 123-133.

BoDOLAY I. 1966. A széleróziót befolyásoló változó talajfizikai tulajdonságok, Agrokémia és Talajtan. 15. (1-2) 372-383.

BODOLAY I., MÁTÉ, F., SzŰCS, L. 1976. A szélerózió hatása a Bácskai-löszháton, Agrokémia és Talajtan. 25. (1-2) 96-103.

Bolles K., SwEENy M., Forman S. 2019. Meteorological catalysts of dust events and particle source dynamics of affected soils during the 1930s Dust Bowl drought, Southern High Plains. USA Anthropocene. 27. 100216.

BORELLI J., GREGORY J.M., ABTEW W. 1989. Wind Barriers: A Reevaluation of Height, Spacing, and Porosity. Transactions of the ASAE. 32 . (6) 2023-2027.

BORSY Z. 1972. A szélerózió vizsgálata a magyarországi futóhomok területeken. Földrajzi Közlemények. 20. (2-3) 156-160.

CARlson, J.R., EkBlad, S.L., TibKe, G.L. 1999. Deployment, Support, and Use of Wind Erosion Equation (WEQ). - Software for Resource Analysis and Planning.

CHEPIL W.S. 1945a. Dynamics of winderosion 1. Nature of movement of soil by wind. Soil Science. 9. 71-134.

CHEPIL W.S. 1945b. Dynamics of winderosion 2. Initiation of soil movement. Soil Science. 60. 397-410.

CHEPIL W.S., WoOdRUFF N.P. 1963. The physics of winderosion and its control. Advences in Agronomy. 13. 211-302.

Csorba P., Blanka V., Vass R., NAGy R., MezŐsI G., Meyer, B. 2012. Hazai tájak müködésének veszélyeztetettsége új klímaváltozási előrejelzés alapján. Földrajzi Közlemények. 136. (3) 237-253.

ChePIL W. S. 1957. Dustbowl: Causes and effects. J. Soil and Water Conserv. 12. 108-111.

CHEPIL W.S., WoOdRUFF N.P. 1963. The physics of winderosion and its control Advances in agronomy. 13. 211-299.

DONG Z., SUN H., ZHAO A. 2004. WITSEG sampler: a segmented sandsampler for windtunnel test. Geomorphology. 59. (1-4) 119-129.

DREGNE H.E. 1988. Winderosion: an international perspective. Proceedings of Wind Erosion Conference. Lubbock, Texas. pp. 175-182.

DöVÉNYI Z. (szerk.) 2010. Magyarország kistájainak katasztere. Második, átdolgozott és bővített kiadás, Magyar Tudományos Akadémia, Budapest.

FARSANG A. 2016. A víz és szélerózió szerepe a talaj humusz- és elemtartalmának horizontális átrendeződésében. MTA Doktori Értekezés.

FARSANG A., SZATMÁRI J., NÉGYesi G., BARTUS M., BARTA K. 2011. Csernozjom talajok szélerózió okozta tápanyag-áthalmozódásának becslése szélcsatornakísérletekkel Agrokémia és Talajtan. 60. 87-102. 
Farsang A., Duttmann R., Bartus M., Szatmári J., Barta K., Bozsó G. 2013a. Estimation of Soil Material Transportation by Wind. Based on in Situ Wind Tunnel Experiments. Journal of Environmental Geography. 6. (3-4) 13-20.

FARSANG A., BARTUs M., BARTA K., SzATMÁRi J. 2013b. Csernozjom talajok in situ széleróziós vizsgálata terepi szélcsatornával, Talajvédelem. (Különszám) pp. 157-169.

FARSANG A., BARTus M., BARTA K., SzATMÁRI J. 2017. Szerkezetes talajok deflációérzékenységének és talajtani tulajdonságainak összefüggései: terepi szélcsatorna kísérletek eredményei Dél-alföldi csernozjom talajokon, Földrajzi Közlemények. 141. (1) 1-13.

FrYREAR D.W., SKIDMORE E.L. 1985. Methods for controlling wind erosion. In: Soil Erosion and Crop Productivity. R.F. FolletT AND B. A. STEWART (eds.). Chapt. 24. American Society of Agronomy, Madison, Wisconsin. pp. 443-457.

Goossens, D., OfFer, Z., London, G. 2000.Windtunnel and field calibration of five aeolian sand traps, Geomorphology. 35. 233-252.

Kertész Á., HuszÁr T., Tóth A. 2000. Soil Erosion Assessment and Modelling. In: Physicogeographical Research in Hungary (ed.: KERTÉSz Á. et. al.) Studies in Geographical Research Inst. HAS, Budapest. pp. 63-74.

KovÁCS F. 2006. Tájváltozások értékelése geoinformatikai módszerekkel a DunaTisza közén különös tekintettel a szárazodás problémájára. $\mathrm{PhD}$ értekezés

Kouchami-SARdoO I., ShIRANi H., EsFANDIARPOUR-BOROUJENi I., ÁllvaroFUENTES J., SHEKOFTEH H. 2019. Optimal feature selection for prediction of wind erosion threshold friction velocity using a modified evolution algorithm. Geoderma 354. 113873.

Leys J.F., Heidenreich S.K., Strong C.L., MCTainsh G.H., Quigley S. 2011. PM 10 concentrations and masstransport during "Red Dawn" - Sydney 23 September 2009. Aeolian Research. 3. 327-342.

LÓKI J. 1994. Mezőgazdaság-központú természetföldrajzi vizsgálatok a Duna-Tisza köze É-i felének példáján. Kandidátusi értekezés. Debrecen.

LÓKI J. 2000. The study of winderosionon different soil by windtunnel. In: Anthropogenic aspects of landscape transformations 1. Proceeding of Hungarian-Polish Symposium. (ed.: LÓKI J. \& SzABÓ J.) Debrecen. pp. 37-44.

LÓKI J. 2001. A hazai széleróziós kutatások matematikai összefüggései. Földrajzi Konferencia, Szeged. Szegedi Tudományegyetem TTK Természeti Földrajzi Tanszék.

LÓKI J. 2003. A szélerózió mechanizmusa és magyarországi hatásai. MTA doktori értekezés. Debrecen.

LÓKI J., SzABÓ J. 1996. Neuere Windkanaluntersuchungen der Deflations sensibilität von Böden des Ungarischen Tieflandes. Zeitschrift für Geomorphologie. 40. 145-159.

LÓKI J., SzABÓ J. 1997. Az alföldi talajok deflációérzékenységi vizsgálata szélcsatornában. Regionális Agrárkutatási és Vidékfejlesztési Workshop. Kompolt. pp.73-83. 
Mezösi G., Blanka V., BATA T., Kovács F. ÉS MeYer B. 2015. Estimation of regional differences in winderosion sensitivity in Hungary. Natural Hazards Earth System Science. 15. 97-107.

MezŐsI G., Bata T., MeYer B., Blanka V., LADÁNYI Z. 2014. Climate Change Impacts on Environmental Hazards on the Great Hungarian Plain, Carpathian Basin. International Journal of Disaster Risk Science. 5. (2) 136-146.

MEzÖSI G. 1996. The predicted winderosion rate in the Carpathian Basin. Abs. of the IAG ERC'96. Budapest, p. 86.

Michels K., SivaKumar M.V., Allison B.E. 1995. Winderosion control using cropresidue Effects on soil flux and soil properties. Field Crops Research. 40. 101-110.

Mika J., Ambrózy P., Bartholy J., Nemes Cs., PÁlvölgyi T. 1995. Az Alföld éghajlatának időbeli változékonysága és változási tendenciái a hazai szakirodalom tükrében. Vízügyi közlemények LXXVII. 262-283.

NÉGYESI G., LÓKI J., BURÓ B., SZABÓ S. 2016. Effect of soil parameters on the threshold wind velocity and maximum eroded mass in a dry environment Arabian Journal of Geosciences. 9. 588-598.

PÁsZTOR L., NÉGYesi G., LABOrCZI A., KovÁCs T., LÁSZló E., Bihari Z. 2016. Integratedspatialassessment of winderosion risk in Hungary, Naural Hazards Earth System Science. 16. 2421-2432.

Shahabinejad N., Mahmoodabadi M., Jalalian A., Chavoshi E. 2019. The fractionation of soil aggregates associated with primary particles influencing wind erosion rates in arid to semiarid environments. Geoderma. 356. 113936.

Stefanovits P., Filep G., FÜleKY G. 2010. Talajtan. Mezőgazda Kiadó, Budapest.

SZATMÁRI, J. 2006. Geoinformatikai módszerek és folyamatmodellek alkalmazása a széleróziós vizsgálatokban, Doktori $(\mathrm{PhD})$ értekezés. Kézirat. Szegedi Tudományegyetem.

TATARKOJ.,SPORCIC M. A.,SKIDMORE E.L. 2013. A history of winderosion prediction models in the United States Department of Agriculture prior to the Wind Erosion Prediction System, Aeolian Research. 10. 3-8.

TATÁRVÁRI K. ÉS NÉGYESI G. 2013. Néhány Duna-Tisza közi talaj szélerózió hatására bekövetkező tápelem vesztesége szélcsatorna kísérletek alapján. Agrokémia és Talajtan. 62. (2) 285-298.

Touré A.A., Tidjani A.D., RAJot J.L., Marticorena B., BergametTi G., Bouet C., Ambouta K.J.M., Garba Z. 2019. Dynamics of wind erosion and impact of vegetation cover and land use in the Sahel: A case study on sandy dunes in southeastern Niger. Catena. 177. 272-285.

Vigiak, O., Sterk, G., Warren, A., Hagen, L.J. 2003. Spatial modelling of windspeed around wind breaks. Catena. 52. 273-288.

WANG R., LI. Q., ZHOU N., CHANG C., GUO Z., LI J. 2019. Effect of wind speed on aggregate size distribution of windblown sediment. Aeolian Research. 36. 1-8.

WeIDINGER T., BARTHOLY J., MATYASOVSZKY I. 2000. A globális éghajlatváltozás lokális hatásainak vizsgálata hazánkban. Földrajzi Közlemények. 124. (1-4) 75-92. 
Weinan C., Zhibao D., Zhenshan L., ZuOtao Y. 1996. Windtunnel test of the influence of moisture on the erodibility of loessial sandyloam soils by wind. Journal of Arid Environments. 34. 391-402.

Zhang C., ZoU X., Gong, J., LiU L., LIU Y. 2004. Aerodynamic roughness of cultivated soil and its influence on soil erosion by wind in a wind tunnel. Soil \& Tillage Research. 75. 53-59.

\title{
Windtunnel experiments based wind erosion risk estimation of soil surfaces in Csongrád County
}

\author{
*M. BARTUS, K. BARTA, J. SZATMÁRI, A. FARSANG \\ Department of Physical Geography and Geoinformatics, University of Szeged, Szeged
}

\section{Summary}

In Hungary, the wind erosion hazard of the soil surface would be increased due to the global climate changing in the next few decades (CSORBA et al. 2012). This paper aims to determine the effect of soil properties on threshold friction velocity and estimate the recent wind erosion hazard of the Southern part of the Great Hungarian Plain.

Sample areas were selected from the vicinity of Szeged. Based on this study it has been proved that the macro-aggregate $(10.0-0.25 \mathrm{~mm})$ fraction of agronomic structure has the biggest effect on threshold friction velocity. This result should draw attention to the importance of the adequate agronomy practices in the control of wind erosion (Bodolay 1966; SHAHABINEJAD et al. 2019). The wind tunnel threshold friction measurements have been combined with weather data, based on this method a wind erosion map has been determined to the area of Csongrád County. The yearly wind erosion events' numbers have also been determined (sand: 16.8 events; sandy loam and loam: 1.6 events; clayed loam: 0.4 event) as well as the average time period of these events (sand: 3.0 hours; sandy loam and loam: 1.4 hours; clayed loam: 1.0 hour). In Csongrád County the wind erosion affected area reaches $57.5 \%$ of the County (in details: sand: $8.4 \%$; sandy loam and loam $29.1 \%$; clayed loam: $20.0 \%$ ).

Based on these results we received an overview about the importance and extension of wind erosion hazard in Csongrád County. Our previous studies proved that even a few-minute-long wind erosion event can cause devastating effect on soil's nutrition properties (FARSANG et al. 2011, FARSANG 2016).

\section{Tables and figures}

Table 1. Threshold friction velocity and aerodynamic roughness of different soil structures in Southern part of the Great Hungarian Plain.; (1) Texturalstructure, (2) Sand, (3) Sandy loam, (4) Loam, (5) Clayed loam, (6) Clay, (a) Sample number, (b) Ex-situ measured threshold friction velocity at $10 \mathrm{~cm}$ 
height, (c) Standard deviation of ex-situ measured threshold friction velocity at $10 \mathrm{~cm}$ height, (d) Threshold friction velocity at $10 \mathrm{~m}$ height, corrected by insitu measurements, (e) Standard deviation of threshold friction velocity at 10 meters height, corrected by in-situ measurements, (f) Aerodynamical roughness, (g) Standard deviation of aerodynamical roughness, *Ex-situ measured threshold friction velocity at $10 \mathrm{~cm}$ height, **Threshold friction velocity at $10 \mathrm{~m}$ height, corrected by in-situ measurements, ***Aerodynamical roughness, n.é. Not applicable.

Table 2. Wind erosion hazard of the soil structures in Csongrád County (based on 2000-2019 SYNOP data); (1) Textural-structure, (2) Sand, (3) Sandy loam Loam, (4) Clayed loam, (a) Yearly average of wind erosion length (hour year $\left.^{-1}\right)$, (b)Yearly average number of wind erosion events (event), (c)Average length of the wind erosion events (hour).

Table 3. Extension of the wind erosion effected areas in Csongrád County, according to land use; (1) Textural-structure, (2) Sand, (3) Sandy loam - Loam, (4) Clayed loam,(a) Affected area in Csongrád County $\left(\mathrm{km}^{2}\right)$, (b) Affected area in Csongrád County (\%).

Figure 1. Soil sampling points near Szeged (circle refers to ex-situ sampling points, square refers to in-situ and ex-situ sampling point); (1) in-situ and ex-situ sampling points, (2) ex-situ sampling points.

Figure 2. Wind tunnel measurements: wind tunnel (left) and sample container in wind tunnel (right).

Figure 3. Plasticity according to Arany, humus content, total salt content and the medium-size aggregate effects on threshold friction velocity; (I.) Relation of plasticity according to Arany to the threshold friction velocity, (II.) Relation of humus content to the threshold friction velocity, (III.) Relation of total salt content to the threshold friction velocity, (IV) Relation medium-size aggregate diameter to the threshold friction velocity, (1) Plasticity according to Arany, (2) Wind velocity (m/s), (3) Humus content (\%), (4) Total salt content (\%).

Figure 4. Yearly wind erosion event number of Csongrád County (2000-2019); (1) Legend, (2) Number of yearly wind erosion events.

Equation 1. Wind speed calculation in different altitudes, where: $\mathrm{U}_{\mathrm{z}}$ : wind speed at $\mathrm{Z}$ height; $\mathrm{U}_{0}$ : friction velocity; $\mathrm{C}$ : Von Kármán- constant, value is 0,4 ; $Z$ : height of the wind speed measurements; D: height of displacement; $\mathrm{Z}_{0}$ : aerodynamic roughness. (ZHANG et al. 2009)

Open Access nyilatkozat: A cikk a Creative Commons Attribution 4.0 International License (https://creativecommons.org/licenses/by/4.0) feltételei szerint publikált Open Access közlemény, melynek szellemében a cikk bármilyen médiumban szabadon felhasználható, megosztható és újraközölhető, feltéve, hogy az eredeti szerző és a közlés helye, illetve a CC License linkje és az esetlegesen végrehajtott módosítások feltüntetésre kerülnek. (SID_1) 